 \\ Journal of Drug Delivery and Therapeutics
}

Open Access to Pharmaceutical and Medical Research

(C) 2011-18, publisher and licensee JDDT, This is an Open Access article which permits unrestricted non-commercial use, provided the original work is properly cited

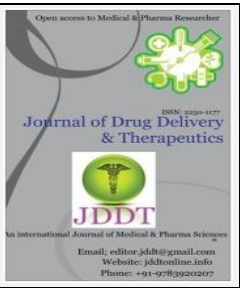

Open $\odot$ Access

Review Article

\section{A report on Nipah Virus}

\author{
Doke Onkar*, Kale Sagar, Mujawar Fatema Begum, More Priyanka, More Tejashri
}

Department of Pharmaceutics, Sahyadri College of Pharmacy, Methwade, Maharashtra, India-413307

\begin{abstract}
Nipah virus, a paramyxovirus related to Hendra virus. Nipah virus first emerged in Malaysia, outbreak continue to occur in Bangladesh and India. In Malaysia-Singapore outbreak transmission occurred primarily through contact with pig. While in Bangladesh and India it is related with ingestion of contaminated date palm sap and human-to-human transmission. Bats are main reservoir for Nipah virus which can cause disease in human and animal. Nipah virus replication well in porcine stable kidney cell and human lung fibroblast cell. Nipah virus is probably spread through cell-to-cell spread mechanism. The Nipah virus has the potential to be considered an agent of bioterrorism.
\end{abstract}

Keywords: Nipah virus; pig; human; transmission

Article Info: Received 24 Jan 2019; $\quad$ Review Completed 20 Feb 2019; $\quad$ Accepted 22 Feb 2019; Available online 15 March 2019

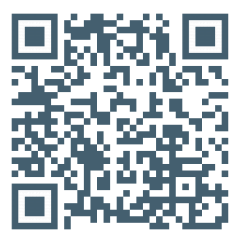

\section{Cite this article as:}

Doke 0, Kale S, Mujawar FB, More P, More T, A report on Nipah Virus, Journal of Drug Delivery and Therapeutics. 2019; 9(2):449-452 http://dx.doi.org/10.22270/jddt.v9i2.2378

\section{*Address for Correspondence:}

Maharashtra, India

Mr. Onkar Bharat Doke, Asst. Professor, Department of Pharmaceutics, Sahyadri College of Pharmacy, Methwade- 413307,

\section{INTRODUCTION}

Nipah virus infection which is popularly known as (NiV) is caused by Nipah virus. The Nipah virus name originated from Sungai Nipah, a village in the Malaysian Peninsula where pig farmers became ill with encephalitis. Nipah is a viral zoonotic disease caused by NiV of the Henipavirus genus of paramyxoviridae family. Fruit bats of the genus Pteropus (flying foxes) are the main reservoir hosts for Nipah virus. They are supposed to be the natural host of the virus. Nipah virus was isolated and identified in 1999 during an outbreak of encephalitis and respiratory illness among pig farmers and people with close contact with pigs in Malaysia and Singapore. In the 1999 outbreak, Nipah virus caused a relatively mild disease in pigs, but nearly 300 human cases with over 100 deaths were reported. In order to stop the outbreak, more than a million pigs were euthanized, causing tremendous trade loss for Malaysia. Since this outbreak, no subsequent cases have been reported in either Malaysia or Singapore.

In 2001, Nipah virus was again identified as the causative agent in an outbreak of human disease occurring in Bangladesh. Genetic sequencing confirmed this virus as Nipah virus, but a strain different from the one identified in 1999. In the same year, another outbreak was identified in Siliguri, India with reports of person-to-person transmission in hospital settings (nosocomial transmission). Unlike the Malaysian Nipah virus outbreak, outbreaks occur almost annually in Bangladesh and have been reported several times in India. $3^{\text {rd }}$ Nipah virus Outbreak was reported in
Kerala. 17 patient deaths have been reported. From Nipah virus Outbreak in Bangladesh and India it is postulated that Outbreak in human may be not only due to direct contact with bats but also indirectly by contact with material contaminated by bats. $1,2,3$

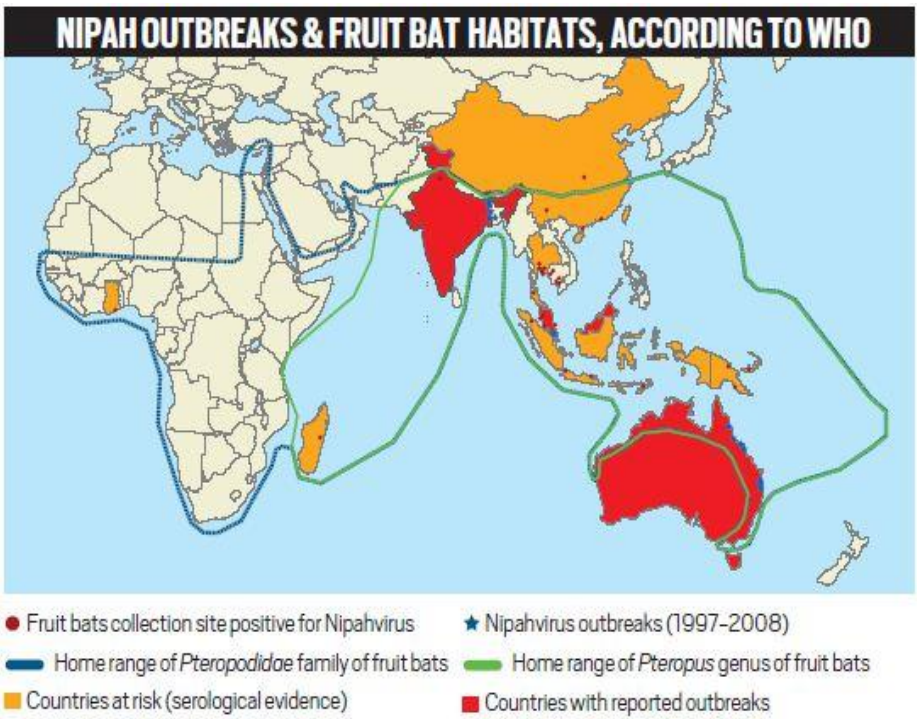

CODEN (USA): JDDTAO 


\section{STRUCTURE OF HENIPAVIRUS}

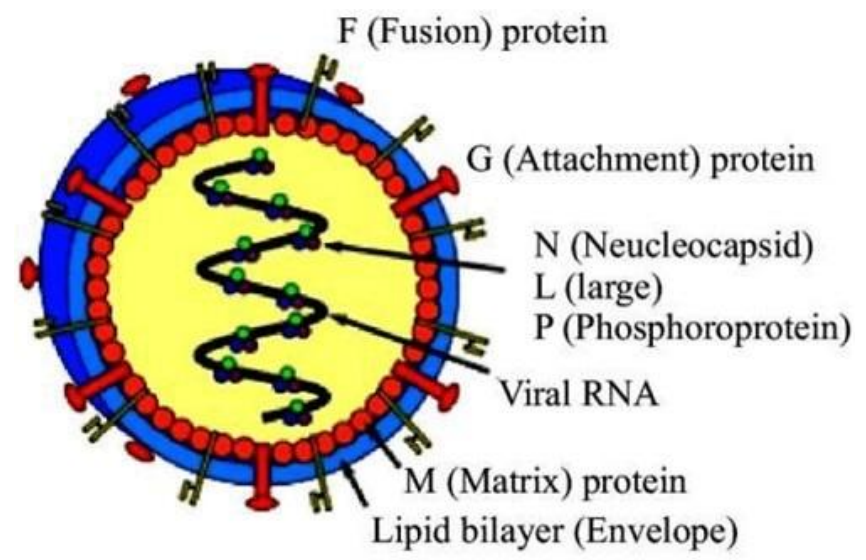

The Nipah virus is a type of RNA virus in the genus Henipa virus. It is pleomorphic after with variable shape it ranges from a size of $40-600 \mathrm{~nm}$ in diameter it contains a single lipid membrane with a shell of viral matrin protein at core there is single stranded RNA which gets tightly bounded to $\mathrm{N}$ (nucleocapsid) protein present with $\mathrm{L}$ (large) and $\mathrm{P}$ (phosphate) protein, which provides polymerase activity during the viral replication. The role of $G$ protein is to attach the virus to host cell surface through EFNB2, a highly conserved protein mostly in mammals. The $\mathrm{F}$ protein involves in the fusion of host and viral membrane which help to transfer of virion content to host cell. ${ }^{4}$

\section{REPLICATION}

The interaction of Nipah virus (NiV) nucleocapsid (N) protein with phosphoprotein (P) during nucleocapsid assembly is the essential process in the viral life cycle, since only the encapsidated RNA genome can be used for replication. Nipah virus (NiV) belongs to the genus Henipavirus within the family Paramyxoviridae. 5

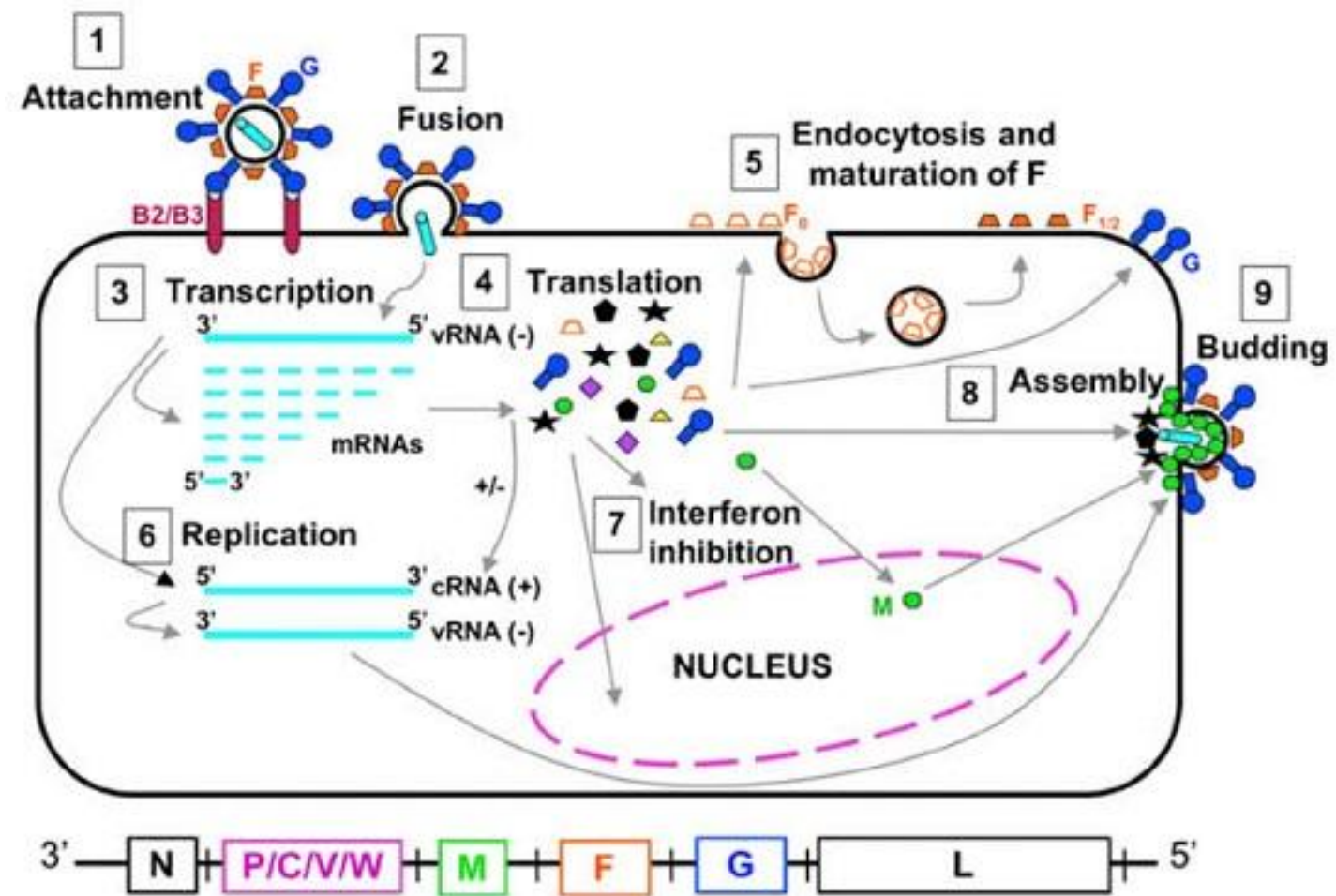

\section{CAUSES}

Nipah virus is a zoonotic virus (it is transmitted from animals to humans) and can also be transmitted through contaminated food or directly between people. In infected people, it causes a range of illnesses from asymptomatic infection to acute respiratory illness and fatal encephalitis. ${ }^{6}$

\section{SIGNS AND SYMPTOMS}

- Fever

- Headache

- Myalgia (Muscle aches)

- Sore throat

- Acute respiratory syndrome or Atypical Pneumonia

- Mental confusion

- Dizziness

- Brain swelling

- Confusion
- Anxiety

- Coma

- Unconsciousness

- Drowsiness

- Disorientation

- Vomitting

- Flue like symptoms like cough, cold

- Shortness of breath

- Choking,

- Stomch ache

- Fatigue

- $\quad$ Blurred vision etc. 7,8,9

\section{INCUBATION PERIOD}

Encephalitis and seizures occur in severe cases, progressing to coma within 24 to 48 hours. The incubation period (interval from infection to the onset of symptoms) is 
believed to range from 4 to 14 days. However, an incubation period as long as 45 days has been reported. ${ }^{1}$

\section{RISK}

The risk of exposure is high for hospital workers and caretakers of those infected with the virus. In Malaysia and Singapore, Nipah virus infection occurred in those with close contact to infected pigs. In Bangladesh and India, the disease has been linked to consumption of raw date palm sap (toddy) and contact with bats. 10

\section{TRANSMISSION}

Transmission of Nipah virus to humans may occur when one comes in direct contact with infected bats, infected pigs or infected people. The recent outbreak of Nipah virus in Kerala (May 2018), occurred when people consumed fruits bit by infected fruit bats. When bats carrying the virus bite into fruits, the virus enters the fruits and then infects the humans who consume it. Bats shed the virus in their excrement and secretions which can infect humans, as well as animals such as pigs, dogs, cows, etc who come into contact with the droppings. The Nipah virus is also suspected to get transmitted through coughing. This infection can also easily affect people who come in direct contact with contaminated bodies.

Nipah virus RNA has been detected in semen from an individual who received treatment for Nipah virus infection, with RNA detected at day 26 following onset of illness (but not at days 42 or 59 ). These findings suggest that there may be a potential risk of sexual transmission of Nipah virus, although the viability of Nipah virus detected in the individual's semen remains unknown, and sexual transmission of Nipah virus has not been described to date.11, 12
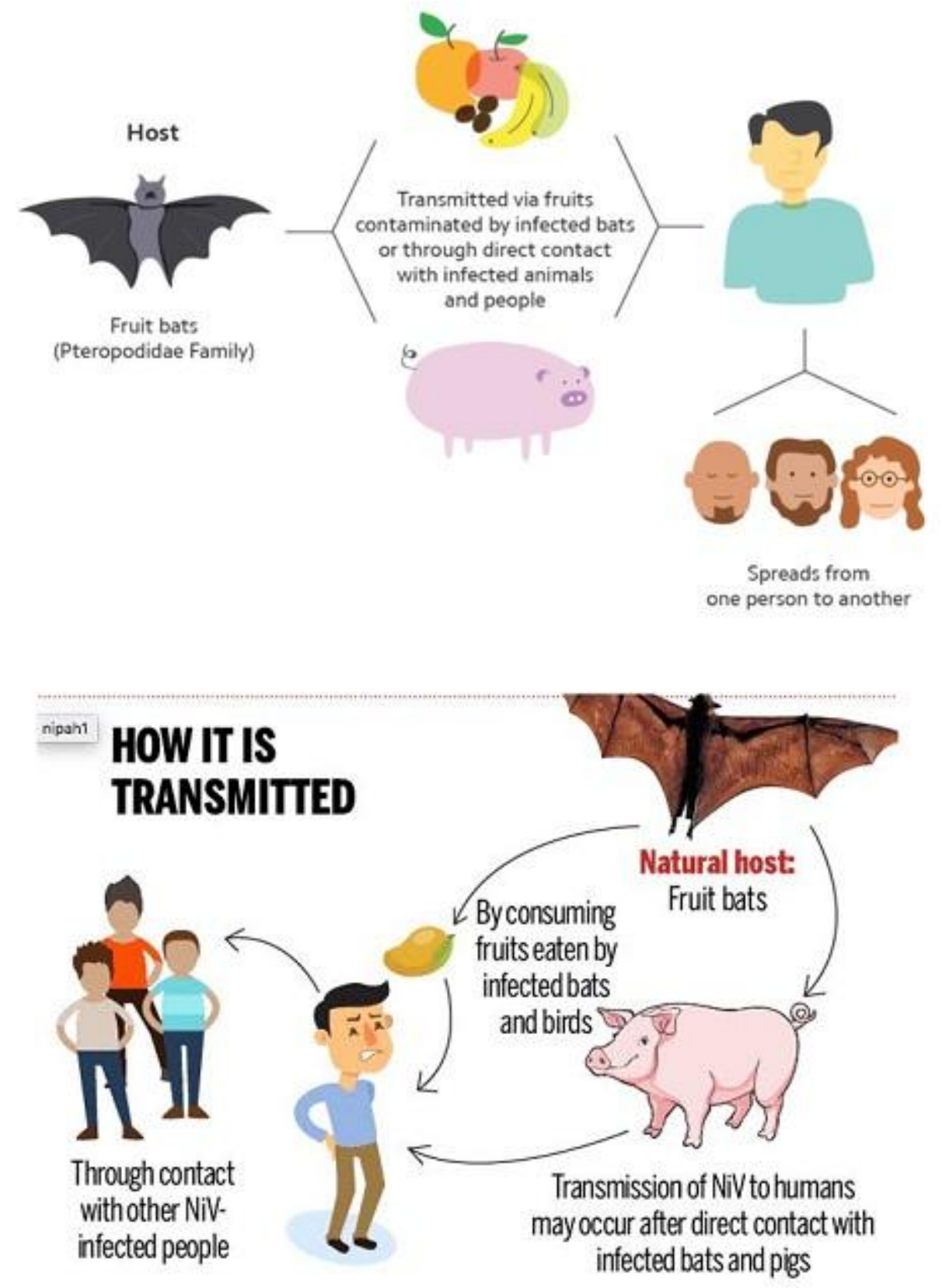


\section{EPIDEMIOLOGY}

The natural animal reservoir of Nipah virus is bats, particularly fruit bats of the Pteropus genus. Nipah virus infections in humans were reported for the first time in 1998, with cases also seen in Singapore. Outbreaks have occurred subsequently in specific districts in Bangladesh and almost annually since 2001. Cases of henipavirus infection have also occurred in the Philippines, believed to have been caused by Nipah virus or a Nipah-like virus. In May 2018 an outbreak was reported in Southern India for the first time, in Kozhikode district of Kerala (see above map). Local fruit bats tested positive for the virus. The outbreak was short lived, with 18 confirmed cases.

Nipah virus has been isolated from the urine of bats in Malaysia, and antibodies against Nipah virus have been detected in 23 species of bat across Asia, and also in bats in Ghana and Madagascar. However, human outbreaks of Nipah virus infection have not been identified outside South and South East Asia, and most outbreaks have occurred in rural or semi-rural locations. ${ }^{13,14}$

\section{PREVENTION}

Prevention of Nipah virus infection is important since there is no effective treatment for disease. The infection can be prevented by,

1. Avoid visiting the endemic area.

2. Avoid fruits that are fallen off from the trees.

3. Avoid sap of raw date palms.

4. Avoid drinks made near the palm trees.

5. Avoid direct contact with bats or pigs in the epidemic areas.

6. Maintain absolute general hygiene, wash your hands frequently.

There is no vaccine against Nipah virus. A number of researches have been successfully conducted on the development of vaccines. To date, prevention of Nipah virus infection relies on veterinary measure in domestic animal and public health education $.1,15$

\section{DIAGNOSIS}

Laboratory diagnosis of Nipah virus includes,

- Serology,

- Histopathology,

- $\quad$ PCR and virus isolation.

Serum Neutralization Test, ELISA, RT-PCR are used for laboratory confirmation. Bangladesh, India and Thailand have developed laboratory capacity for diagnostic and research purposes. There are a few laboratories in which the virus can be studied safely without a risk of infecting more people. ${ }^{16,17,18}$

\section{TREATMENT}

Currently, there is no any treatment for Nipah virus. The primary treatment is focused on managing the symptoms such as managing the fever and neurological symptoms if any. The only thing that can help a patient suffering from Nipah virus infection is intensive supportive care. Treatment is limited to supportive care although some physicians suggest the drug, Ribavirin, may be useful. A monoclonal antibody targeting the viral G glycoprotein has been beneficial in a ferret model of the disease..$^{1,7}$

\section{REFERENCES}

1. Nipah Virus Infection. The Centre for Food Security and Public Health, Iowa State University, Jan 2016; 1-9.

Available from (http://www.cfsph.iastate.edu/Factsheets/pdfs/nipah.pdf)

2. Safahieh H, Sanni SA, Zainab AN, International Contribution to Nipah Virus Research 1999-2010, Malaysian Journal of Library \& Information Science, 2012; 17(3):35-47.

3. Yadav PD, Raut CG, Shete AM, Mishra AC, Towner JS, Nichol ST, Mourya DT, Short Report: Detection of Nipah Virus RNA in Fruit Bat (Pteropus giganteus) from India, The American Journal of Tropical Medicine \& Hygiene, 2012; 87(3):576-578.

4. Chanchal DK, Alok S, Sabharwal M, Bijauliya RK, Rashi S, Nipah: Silently Rising Infection, International Journal of Pharmaceutical Sciences and Research, 2018; 9 Suppl 8:31283135.

5. Chang LY, AbuBakar S, Nipah virus: Phylogeny and replication, Neurology Asia, 2009; 14:63-66.

6. Nipah. Fast Facts, The Centre for Food Security and Public Health, Iowa State University, Apr 2008: 1.

7. Nipah Virus, National Center for Emerging and Zoonotic Infectious Diseases, Centers for Disease Control and Prevention, 2015; 1-3. Available from f www.cdc.gov/vhf/nipah/).

8. Rahman M, Husain MM, National Guideline for Management, Prevention and Control of Nipah Virus Infection including Encephalitis, Dec 2011.1-68.

9. Nipah Virus Infection, WHO: 1-9.

10. Luby, Stephen P, Gurley, Emily S, Transmission of Human Infection with Nipah Virus. National Academies Press, Archived from the original on May 2018, Retrieved May 2018.

11. Giangaspero M, Nipah Virus, Tropical Medicine \& Surgery, 2013; 1(4):1-8.

12. Nipah Virus, Division of Disease Control, Mar 2016: 1-2.

13. Nipah Virus, The Centre for Food Security and Public Health, Iowa State University, 2015: 1-12.

14. Nipah Aetiology Epidemiology Diagnosis Prevention and Control References, OIE Scientific and Technical Department, 2009: 1-5.

15. Nipah Virus, Centers for Disease Control and Prevention, 2018. Available from (https://www.cdc.gov/vhf/nipah/prevention/index.html)

16. Kulkarni DD, Tosh C, Venkatesh G, Nipah virus infection: Current scenario, Indian Journal of Virology, 2013; 1-9.

17. Nipah Virus, WHO Fact sheets May 2018, Available from (https://www.who.int/news-room/fact-sheets/detail/nipahvirus)

18. Narasiman M, Laboratory Diagnosis of Nipah Virus Infection, Available from Research Gate (Conference Paper), 2015. 